\title{
The Trade and Commerce in Early Bengal Till the Establishment of the Muslim rule with Special Reference to the System of Coinage
}

\begin{abstract}
Abhijit Datta,
ABSTRACT

Bengal has a glaring history of brisk commercial connection with different parts of Asia and Africa since long past. There are plenty of evidences in our store to irradiate important information upon that aspect of history. Controversy has loomed large upon the scholars about the character of trade after the emergence of feudalism in that area after the fall of the Imperial Guptas. In spite of vicissitudes of opinion over the matter it cannot be denied that the volume of trade was hardly affected by the development of that trait in the political - social history of Bengal. Feudalism in Bengal has had hardly any bearing with the running trade and commerce and with the feudal character of the society.
\end{abstract}

Key Words: Feudalism, Overseas Trade, Coins, Agriculture

*Kshudiram Pally, Sukanta Smriti Bidyapith, Islampur, India 
The different areas of early Bengal, covering an area of 80,000 square miles ${ }^{1}$ with an immense source of alluvial deposit between the Tippara hills in the East, the Shillong plateau and Nepalese Terai in the North and the high lands of the Rajmahal and Chhjotanagpur in the West, with the Janapadas of GaudaPundra-Varendra-Radha-Sumha-Tamralipti-Samatata-Vañga-VañgālaHarikela watered by the Bhāgirathī-Karatoyā-Brahamaputra-Padmā-Meghnā and many other tributories ${ }^{2}$, played a very significant part in molding the history of ancient India.

\section{Trade and Commerce}

Trade and commerce formed an important part of the economic life of Bengal since remote past. It was a source of prosperity of Bengal which is attested by the accounts of various ancient sources. Human life in the Delta has been deeply influenced by the rivers and the variations of monsoonal climate ${ }^{3}$.The great rivers of Bengal had played a significant part in the agrarian production of the area. Besides renewing fields, the rivers carried immense number of fish which provided a readymade source of food to the Delta dwellers. Moreover the alluvial soil of the region resulted in the huge agrarian production. The warm humid climate, in conjunction with the fertility of land, made the region an extra ordinary productive agricultural land capable of supporting a large surplus consuming class. The surplus production caused by the above factors fostered the trade and commerce of the region. Over and above the gulf region of the South-eastern part of Bengal and so also many navigable rivers with natural ports aggravated the trade and commerce facilities of the region. The network, of rivers provided a readymade system of interconnecting waterways for easy communications and economical transportation ${ }^{4}$. Similarly the qualitative and quantitative development of Bengal's production accelerated the process of the trade and commerce of the region.

We have dearth of information regarding our inland commerce in the remote past. The inscriptional sources shed little light in that respect. On the other hand the writings of the foreign travellers and historians do not come much

1 T.P.Morgan and W.G.Mc Intire, "Quatunary geology of the Bengal Basin, East Pakistan and India" in "Bulletin of the Geological Society of America, LXX(1959)",pp 319-42.

2 N.R.Roy, Bangalir Itihas ,Adiparva,Pratham Khanda,1356B.S, P - 17

3 B.M.Morrison, Political Centres and Cultural regions of early Bengal, $\mathrm{P}-10$

4 Op.cit. 
to our assistance because the interests of the foreign travellers lay in the foreign trade of the province. The development of foreign trade of which our sources of information are plenty, asserts the existence of certain amount of internal trade of the region. There are references to officials for collecting tolls (Saulkika) and supervisors of marts and markets (hattapati) and officerin- charge of markets, customs, tolls and ferries which indirectly testify to the existence of brisk nature of internal trade and prove that the state derived from it a considerable revenue. The centres of inland trade were the towns. It has been gleaned from the inscriptional sources of Gopachandra, Dharmaditya and Samachjaradeva ${ }^{6}$ that Navyavakāsika was the centre of merchants and businessmen. The inscriptions of Budha Gupta and Kumaragupta also give the similar information about the status of city of Kotivarsha ${ }^{7}$. We have references to ships and the dockyards and to custom officers called 'Vyāpāra - Kārandaya' or Vyāpārānḍua in the two grants of the time of Dharmāditya and Vyāpāraya-viniyukta in the grant of Dharmāditya nand Vyāpāraya-viniyukta in the grant of Gopachandra. They were obviously officials in charge of the duty of looking after trade and commerce. The rivers of the province and proximity of the Orissa and Chittagong coasts afforded great facilities for riverine and coastal trade. There can be no doubt that a large number of people were engaged in shipping and the province must have carried on brisk trade and such a department of commerce must have been an important source of revenue. Its duties would have been to levy custom dues on foreign trade and on internal trade. It must have been, as Pargiter has pointed out, a most lucrative office ${ }^{8}$. It is known from the Kathā-saritasāgara that Pundravardhana had a great market place and its streets were lined with shops. Villages were also often centres of trade and business. There are references to hatta or market in the Dāmadarapur copper plate of Kumarāgupta ${ }^{9}$ and Hattika in the Khālimpur plate of Dharamapala ${ }^{10}$. The grant of villages with its market placed (sa-hatta) ${ }^{11}$,

$5 \quad$ History of Bengal Vol-I,Dacca University, 1943, PP- $659 \mathrm{ffl}$

6 The Faridpur Copper plate of Gopachandra, D.C.Sircar, Select Inscriptions bearing Indian Hisotry and Civilisation, p- 370; Indian Antiquary, 1910, P 20; The Faridpur plate of Dharmaditya, Indian Antiquary , 1910, p-195; The Faridpur plate of Samacharadeva, unpublished.

7 The Damadarpur plate of Kumara Gupta, Epigraphia Indica XV, P-130. The Damadarpur plate of Budha Gupta, Epigraphia Indica , XV, P- 133

8 Indian Antiquary (1910), p- 212

9 Epigraphia Indica, XV, P- 133

10 Ibid., p- 138 
shops (hattiya-griha) and big markets (hatta-vara) ${ }^{12}$ speaks of the existence of lucrative trade in village in ancient and early medieval Bengal. Though the rivers and canals of Bengal were the chief routes of internal trade, there were land routes also connecting different parts of the province. These are referred to by foreign travelers like Fā-hien and Hiuen-Tsāng and the mention is made of 'rāja-patha' or public highway passing b y a village in the Chittagong copper plate of Damodaradeva ${ }^{13}$.

We have got much more information about the overseas trade of Bengal. The reason is probably that the oversea trade of a large part of North India passed through Bengal and its well-known ports were at the mouths of the Ganges. Strabo, the Greek geographer and historian, who wrote his famous 'Geography' between A.D. 17 and 23, refers to the "Ascent of vessels from the sea by the Ganges to Palibothra"14. We further come to know from the Jataka stories ${ }^{15}$ that the merchant took ships at Benaras or lower down at Champa (modern Bhagalpur) and then either made coasting voyage to Ceylon or crossed the Bay of Bengal to Suvarnabhûmi. We also learn from the 'Periplus of the Erythreaean Sea' that Bengal maintained an active oversea trade with South India and Ceylon in the first Century A.D. Articles like malabathrum, Gangetic spikenard, pearls and Muslins of the finest sorts were exported."These were all shipped from a market town called Gange (Probably the same as Tamralipta)".According to Milinda Pãñha, the trade was carried on from Vanga across the sea to many countries ${ }^{16}$. Among the important ports of ancient Bengal, mention should invariably be made of Tamralipta.It is hardly necessary to stress the fact that in all periods the city which controlled the mouth of the Ganges was commercially the most important in Eastern India, just as the city which controlled the gates of the Euxine was commercially the most important in Hellas ${ }^{17}$.

Now there is a controversy among the scholars about the position of trade and commerce in the post-Gupta period. According to the prominent historian R.S.Sharma India, in Post Gupta period exhibited the characteristic of feudalism involving payment of services in land instead of coins which

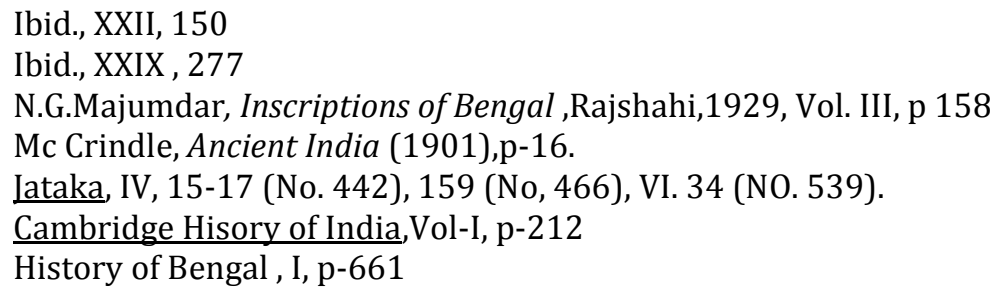


developed in an economy marked by the dearth of coins and the absence of trade and commerce. ${ }^{18}$ But D.C.Sircar holds that the above theory is incorrect. According to him, there is no evidence of any real dearth of coins in Indian markets during the early and medieval period ${ }^{19}$. So the theory of Marxist historians that feudalism in the early medieval period was marked by the absence of trade and money economy does not bear scrutiny at least in Vanga-Samatata-Harikela as we have enough evidence in favour of the brisk trade of south east Bengal ${ }^{20}$. Perhaps a standard currency was no longer needed for measuring the prices of commodities in terms of money, for trade

18 R.S.Sharma, Indian feudalism, 1965 pp 58 ff; D.C.Sircar has pointed out that land lords of ancient and medieval India should not be confused with the feudal barons of Europe.The Indian Kings were never the real owners of lands under permanent tenants. Most of the donors were the Brahamanas and the temple authorities. The priestly class also obviously not suitable for rendering services of feudal type. It is recorded in most of the charters that the donors were exempted from all kinds of obligations. Generally the object of the grant is stated to have been the religious merit and fame of the donor and his parents. The land was not usually granted to the people of the warrior and other classes. The successor of the donor was not required to pay any amount of money or any kind of presents to the King for obtaining the renewal of grant and the records generally state that the land would automatically pass to the donee's heirs. In India the social position of the Brahmanas were exceptionally high and they were never looked upon as King's vassal. But in the feudal system of Europe, the man who held land from another was considered to be dependent and subordinate of the latter.

Land system and feudalism in Ancient India, Ed by D.C.Sircar, Calcutta University , 1966 pp 57-62

19 D.C.Sircar, Aspects of early Indian Economic Life , P 20 ; Some scholars believe that there was decline in the process of urbanization in the whole of Indian subcontinent on the basis of archaeological and numismatic evidences. R.S.Sharma, however, believes that there was revival of urbanism in the country from 1000 A.D. onwards probably with the arrival of Turks, but we have reasons to believe that in spite of the prevailing decay of urbanism, as postulated by the scholars, there are signs of brisk commercial activity in South-Eastern deltaic Bengal .This commercial activity could not grow in isolation, rather judging by the nature of the volume of trade and commercial activities and finds of large quantity of coinage of precious metals from the excavated sites of Maināmati and surrounding areas, it seems to us that the mighty Kingdoms of the Palas the Senas and others might have used the Pala-Sena territories covering almost the whole of Bengal for the purpose of trade and otherwise it could not have carried on such volume of trade.;P.K.Bhattacharyya," Numismatic Evidence - its relevance in the Socio Economic History of Early Bengal",presidential Address , Paschim -banga Itihas Samsad, Annual Conference held at Uluberia, 1992

20 A critical approach to the trade and commerce in Vanga-Samatata-Harikela during the early medieval period" by Dr. Gaur Chandra Ghosh and Abhijit Datta published in Barnalipi ,Vol-I, Issue-VI,April,2012 
by barter or through cowries became usual practice in the country where foreign trade was either non-existent or negligible. South-East Bengal had altogether a different feature. The regional rulers felt the necessity of maintaining metallic currency obviously for the purpose of catering to the economic needs of the country.

\section{Trade Routes}

Regarding the trade routes, we have got some information from several sources. We are here going to highlight only the main routes. The oversea grade of Bengal from Tamralipta followed different courses. The first course was along the eastern coast of the Bay of Bengal right up to Malay Peninsula and then through the Malay straits to South-East Asia as far as China. The second was the coastal voyage to Palaura near modern Chicacole and then right across the Bay of Bengal to the opposite coast.The third route was along the eastern coast of India to Ceylon and then turning north along the western coast to the mouth the Indus and then up to the ports of Arabia and Eastern Africa $^{21}$.

Regarding the land routes which connected the north-eastern, northern and western India with this region we have got some information. One of them connected Bengal with Kamarupa and China. Hiuen-Tsang travelled through this route in the $7^{\text {th }}$ Century A.D ${ }^{22}$. This route was continued upto the $9^{\text {th }}$ Century A.D. Another route following the Ganges joined the network of highways which converged at Benaras. Merchants travelled from different areas of Bengal to Ayodhya, Pataliputra etc. through this road. Another important land route passed through the Himalayas across Nepal, Sikkim and Chumbi valley to Tibet and China. Another important land route followed the coast of Kalinga and ran up to South Indian peninsula.

\section{Coinage of Bengal}

A gold coin of the imitation Gupta type was discovered in course of excavation at Mainamati near Comilla in East Bengal. The gold coin has been assigned to the Deva dynasty because it is said that the legend Bangāla Mrigānka is also found on the seal attached to King Bhavadeva's plate

\footnotetext{
R.C.Majumdar,History_Ancient Bengal ,Calcuta,1971, P 346

Beal , Buddhist Records of the Western World, London, 1906 , Vol. III, 195
} 
discovered at the Sālvan Vihār site on the Maināmati hill23. The excavations at Mainamati further yielded 52 silver coins (of three denomination), 172 silver coins of the highest denomination of the same type, the majority of which bear the legend Patikera (known to have been an early Medieval city near the Maināmatī hills) ${ }^{24}$.With the end of the rule of Bhavadeva of the Deva dynasty towards the end of the $7^{\text {th }}$ or in the early $8^{\text {th }}$ Century A.D. , the gold specie ended in the territories of Samatata 25 .

The series was supplanted by a class of silver specie bearing the regional name Pattikeda. It was based, typologically and metrologically, on the silver coins of Harikela ${ }^{26}$. Harikela region witnessed, in the $7^{\text {th }}$ and $8^{\text {th }}$ Century A.D, the circulation of a series of highly pure silver coins based, typologically and metrologically, on the coinages of the Chandras of Arakan(A coin of full unit weigh C. 8gms., a piece of three quarter unit c. 6 . Gms, a specimen of half unit c 4 gms, and a sample of quarter unit c. 2 gms.) However the weight standard was changed and the flan was gradually made broader and thinner indicating the transition to second series. Palaeographic features of the legend (Harikela) on different coins indicated the circulation of series II from the 8th $/ 9^{\text {th }}$ to the $12^{\text {th }} / 13^{\text {th }}$ Century A.D. when at times parts of Harikela were in the Pala or Sena Kingdom ${ }^{27}$.

It is known from the available data that a complex system of currency prevailed in the Pāla Sena age (750-1206A.D.).Its base was maintained by Kapardakas or cowries. No metallic money was coined in the major portion of the Pala or Sena Kingdom ${ }^{28}$. However some outside coins could have found their way to the territories of Bengal by way of trade and could have been used according to their intrinsic worth. The same silver coin popular in Northern India during the early medieval period is mentioned as Dramma in the Bodhgaya inscription of Dharmapala (775-872A.D.) ${ }^{29}$. as Purāna in the Bhaturiya inscription of Rājyapāla (917-52A.D) ${ }^{30}$ and as Kārshapaṇa in the

${ }^{23}$ F . A. Khan, Further Excavation in East Pakistan: Mainamati ,pp. 26-27

${ }^{24}$ D.C.Sircar, Aspects of Early Indian Economic Life, p 69

25 B.N.Mukherjee, Post Gupta Coinage of Bengal, pp27-32

${ }^{26}$ B.N.Mukherjee "Some observation on the Coins of Pattikeda (Pattikeda or Pattikera)"Journal of the Varendra Research Museum, Vol.IV „1975-76, PP $19 \mathrm{ff}$

27 B.N.Mukherjee , "Monetary System in Bengal " Numismatic Studies , II , PP 31 ff.

28 Ibid,P-32

29 A.K.Maitreya, Gaudalekhamala(in Bengali) ,Rajshahi,PP $29 \mathrm{ff}$.

30 Epigraphia Indica XXXII, p. 154 
Gayā inscription ${ }^{31}$ of Govindapala, though the last document also records the transaction in which the money was paid in Kapardakas or cowries ${ }^{32}$. But large scale transactions could have been done regularly in units of silver and gold dusts (the former weighing 32 rattis and the latter 80 rattis) ${ }^{33}$. Each unit of silver dust conformed to the weight standard of silver Purana which was equal to 1280 cowries and each unit of gold 'dust' conformed to the weight standard of gold suvarna which was equivalent to 20480 cowries $^{34}$. Thus "dust" silver and gold money had exchange relations with the cowrie money. On the other hand the units of silver dust (mentioned as Chürnī in epigraphs) were exchangeable with the silver coin of Harikela having Purāna weight standard. The Mehar plate of Damodaradeva of the Saka era 1156, which equates purāna with Chūrṇi, suggests also the use of cowries (regulated numbers of which were equal in value of different fractions of Purāna or Chūrnīi ${ }^{35}$. Silver coinage was maintained in Harikela because of the comparatively higher pressure of trade. This area probably had enough quantity of silver imported from outside, but genuine copper do not appear to have been minted in the zone and period in question. The purpose of using copper coins for carrying on daily transaction of small value was perhaps served by cowries ${ }^{36}$.

On the basis of above observations, based on the latest researches, it may be suggested that the different geographical divisions of early Bengal did not have uniform system of coinage. The development of currency in one region did not always lead to the similar development in other regions. Coins played an important role in the economic life of the people of Pundra and Radha regions of early Bengal from the Maurya to the Gupta Age.Excavations in those regions clearly suggest that Pundravardhana and Radha regions were more prosperous than other regions from the Maurya to the Gupta age. These regions carried on international trade through the ports of Ganga and

31 Ibid XXXV, p. 336

32 D.C.Sircar, Early Indian Epigraphic and Numismatic Studies, PP $49 \mathrm{ff}$. According to the Līlāvatī of Bhāskarāchārya of Mahārāshtra who is stated to have been born in 1114 A.D. 20 Cowries=1 Kākinī , 4 Kākinī = 1 pana , 16 panas=1 Dramma and 16 Dramma= 1 Nioshka. D.C.Sircar, Studies in Indian Coins, P 281; According to certain medieval arithmetical tables current in Bengal , 4 cowries = 4 Gaṇḍa , 20 Gaṇḍās= 1 Paṇa and 16 Paṇas = 1 Kāhana (Kārshapaṇa), Ibid., p. 28

33 B.N.Mukherjee, "Monetary System in Bengal "Numismatic Studies, VOl. II p. 32

34 Ibid., pp. $32 \mathrm{ff}$

35 Ibid. pp. 32ff

36 B.N.Muikherjee,"Commerce and Money in the Western and Central Sector of Eastern India, C.A.D.750-1200"Indian Museum Bulletin, Vol. XVII, 1982, pp.68ff. 
Tamralipta during that period ${ }^{37}$.The base of currency in all divisions was mainly maintained by cowries which were imported from outside. The intrinsic value of the cowries being incorruptible, they remained as a stable medium of exchange throughout the long period.

During the post Gupta and especially during the Pāla-Sena time coins began to play significant part in the economic life of the people of the Vangnga, Samatata and Harikela regions. However, the importance of the Radha and Pundra regions in the commercial life continued to about the $7^{\text {th }}$ Century A.D. From about this period Samatata and Harikela regions became gradually more important in respect of internal and international trade. The political and cultural centres of Maināmati and Lālmāi which had grown into urban complex, had a considerable volume of trade sustained by a system of a standard monetary system ${ }^{38}$. But it is hardly probable as P.K.Bhattacharyya has noticed that brisk trade was carried on in the narrow region of SouthEastern Bengal without having any impact over other areas of Bengal. The territories of South-Eastern Bengal might have used other regions of Bengal as hinterland and that augmented the trade and commerce of the area.

The problem of trade and currency in early Bengal has a theoretical bearing on the question of feudalism. The continuation of trade and the existence of currency may not at all negate the possibilities of agrarian economic forms. Moreover the kind of commercial activities could hardly originate a process of urbanization that might bring into being a stable commercialized middle class for profits from trade were either appropriated by foreign merchants or frittered away by feudal lords. Capital formation under these conditions must have been impossible and the realization remained unaffected by trade and money economy.

37 B.N.Mukherjee. "Currency and Money in the Western and Central Sector of Eastern India C A.D. 750-1200" Indian Museum Bulletin, Vol. XXV, 1990, pp. $68 \mathrm{ff}$

38 M.R.Tarafdar "Trade and Society in Early Medieval India" The Indian Historical Review, Vol. XV 
Jhss, Vol. 8, No. 1 , January to June, 2017

\section{REFERENCES}

T.P.Morgan and W.G.Mc Intire, "Quatunary geology of the Bengal Basin, East Pakistan and India" in "Bulletin of the Geological Society of America, LXX (1959)",pp. 319-42

N.R.Roy, Bangalir Itihas ,Adiparva,Pratham Khanda,1356 B.S,

B.M.Morrison, Political Centres and Cultural regions of early Bengal

History of Bengal Vol-I, Dacca University, 1943

The Faridpur Copper plate of Gopachandra, D.C.Sircar, Select Inscriptions bearing Indian Hisotry and Civilisation, , Indian Antiquary, 1910, P 20; The Faridpur plate of Dharmaditya, Indian Antiquary , 1910, p-195; The Faridpur plate of Samacharadeva, unpublished.

The Damadarpur plate of Kumara Gupta, Epigraphia Indica_XV , The Damadarpur plate of Budha Gupta, Epigraphia Indica , XV

N.G.Majumdar, Inscriptions of Bengal , Vol. III, Rajshahi,1929

Mc Crindle, Ancient India (1901)

Jataka, IV , 15-17 (No. 442), 159 (No,466),VI. 34 (NO. 539).

Cambridge Hisory of India,Vol-I

R.S.Sharma, Indian feudalism, 1965 pp 58 ff; D.C.Sircar has pointed out that land lords of ancient and medieval India should not be confused with the feudal barons of Europe.The Indian Kings were never the real owners of lands under permanent tenants. Most of the donors were the Brahamanas and the temple authorities. The priestly class also obviously not suitable for rendering services of feudal type. It is recorded in most of the charters that the donors were exempted from all kinds of obligations. Generally the object of the grant is stated to have been the religious merit and fame of the donor and his parents. The land was not usually granted to the people of the warrior and other classes. The successor of the donor was not required to pay any amount of money or any kind of presents to the King for obtaining the renewal of grant and the records generally state that the land would 
automatically pass to the donee's heirs. In India the social position of the Brahmanas were exceptionally high and they were never looked upon as King's vassal. But in the feudal system of Europe, the man who held land from another was considered to be dependent and subordinate of the latter.

D.C. Sircar (ed.), Land system and feudalism in Ancient India, Calcutta University , 1966

D.C.Sircar , Aspects of early Indian Economic Life , P 20 ; Some scholars believe that there was decline in the process of urbanization in the whole of Indian subcontinent on the basis of archaeological and numismatic evidences. R.S.Sharma, however, believes that there was revival of urbanism in the country from 1000 A.D. onwards probably with the arrival of Turks, but we have reasons to believe that in spite of the prevailing decay of urbanism, as postulated by the scholars, there are signs of brisk commercial activity in South-Eastern deltaic Bengal .This commercial activity could not grow in isolation, rather judging by the nature of the volume of trade and commercial activities and finds of large quantity of coinage of precious metals from the excavated sites of Maināmatī and surrounding areas, it seems to us that the mighty Kingdoms of the Palas the Senas and others might have used the PalaSena territories covering almost the whole of Bengal for the purpose of trade and otherwise it could not have carried on such volume of trade.;P.K.Bhattacharyya," Numismatic Evidence - its relevance in the Socio Economic History of Early Bengal",presidential Address , Paschim -banga Itihas Samsad, Annual Conference held at Uluberia, 1992

Dr. Gaur Chandra Ghosh and Abhijit Datta "A critical approach to the trade and commerce in Vanga-Samatata-Harikela during the early medieval period" Barnalipi, Vol. I, Issue-VI, April,2012

R.C.Majumdar,, History of Ancient Bengal ,Calcuta,1971

Beal , Buddhist Records of the Western World, Vol. III. London, 1906

F . A . Khan , Further Excavation in East Pakistan: Mainamati

B.N.Mukherjee, Post Gupta Coinage of Bengal,

B.N.Mukherjee "Some observation on the Coins of Pattikeda (Pattikeda or Pattikera)"Journal of the Varendra Research Museum, Vol. IV, 1975-76 
Jhss, Vol. 8, No. 1 , January to June, 2017

B.N.Mukherjee, "Monetary System in Bengal" Numismatic Studies, Vol. II

A.K.Maitreya, Gaudalekhamala(in Bengali) , Rajshahi

D.C.Sircar, Early Indian Epigraphic and Numismatic Studies,

B.N.Mukherjee, "Monetary System in Bengal” , Numismatic Studies, Vol. II

D.C.Sircar, Select Inscriptions bearing on the Indian History and Civilization, Vol. II, 1983

B.N.Muikherjee, "Commerce and Money in the Western and Central Sector of Eastern India, C.A.D.750-1200" Indian Museum Bulletin, Vol. XVII, 1982

B.N.Mukherjee, "Currency and Money in the Western and Central Sector of Eastern India C A.D. 750-1200" Indian Museum Bulletin, Vol. XXV, 1990

M.R.Tarafdar "Trade and Society in Early Medieval India" The Indian Historical Review, Vol. XV 